\title{
Phytobiotics in Poultry Industry as Growth Promoters, Antimicrobials and Immunomodulators - A Review
}

\author{
Wafaa A. Abd El-Ghany \\ ${ }^{1}$ Poultry Diseases Department, Faculty of Veterinary Medicine, Cairo University, 1211, Giza, Egypt \\ Corresponding author’s E-mail: wafaa.ghany@yahoo.com; ORCID: 0000-0003-1686-3831
}

Received: 02 Nov. 2020

Accepted: 20 Dec. 2020

\begin{abstract}
Due to the hazardous use of antimicrobials in poultry production sector, development of drug resistance have become a worldwide problem. Therefore, using biotic or natural products, such as phytobiotics (phytogenics or botanicals) have received a great attention as antibiotic substitutes. The use of phytobiotics or their constituents have been considered as a relatively new class of natural herbs that gained popularity and acceptability among poultry farmers. The incorporation of several types of phytobiotic additives in poultry feed have proved their ability to enhance the productive performance of broilers as well as layers. Moreover, phytbiotics presented great efficacy in counteracting intestinal pathogenic microorganism while maintaining the population of normal inhabitant beneficial microflora. Immunostimulatory effect on both humoral and cellular immunity as well as antioxidant properties were recorded as characters of phytobiotics. Therefore, this review article aimed to give a spotlight on the uses of different types of phytobiotics as poultry dietary additives to improve the productive parameters, reduce the pathogenic intestinal bacteria, and potentiate the immune response, especially after vaccination processes.
\end{abstract}

Keywords: Antimicrobial, Immunity, Performance, Plants, Poultry

\section{INTRODUCTION}

From several decades till now, poultry industry has been recognized as an important subsector of agricultural and veterinary fields due to increasing demand for meat and eggs as low cost protein sources. Continues feeding by sub-therapeutic levels of antimicrobials as growth promoter agents or antimicrobial compounds have had a negative impact on the balance of normal inhabitants of gut microflora, accumulation of antibiotic tissues residues as well as developing new strains of drug-resistant pathogenic bacteria (Castanon, 2007). Therefore, in 2006, the European Union Commission banned using of antibiotics in animal feeds as a growth promoter in different countries (Europe Union Commission, 2005).

Phytobiotics are also termed as phytogenics or botanicals. They are defined as natural, less toxic, and residue free plant-derived compounds that have been used as feed additives for livestock production (Wang et al., 2008). Phytobiotics are composed of natural bioactive components or substances of plant origin including terpenoids, alkaloids, glycosides and phenolics (Shad et al., 2014). Phytobiotics could be classified as herbs from flowering, non-woody and non-persistent plants, botanicals or spices from non-leaf parts like seeds, fruits, bark or root, essential oils or extracts and oleoresins (Bote, 2004).

Numerous studies have been conducted to demonstrate the effect of phytobiotics as growth promoter feed additives like prebiotics and probiotics to enhance overall performance parameters as well as health conditions of poultry (Yasodha et al., 2019; Özbudak, 2019). Phytobiotics have been also used as antimicrobial, antiparasitic, anticoccidial as well as immunostimulant agents in poultry field (Manafi, 2015; Gilani et al., 2018; Hafeez et al., 2020). Phytogenic substances were extremely studied in different species of monogastrics (Gheisar and Kim, 2018), rabbits (Alagawany et al., 2018; Al-Sagheer et al., 2019) and fish (Naiel et al., 2019).

So, the purpose of current article review was to spotlight on phytogenic compounds that used in poultry field and their effects on the productive performance, antimicrobial activities and immuno-stimulatory properties. 


\section{Production parameters}

Improved growth parameters were detected in birds fed on different kinds of herbs, polysaccharides or essential oils components (Yasodha et al., 2019). The enhancement of the growth performance parameters after supplementation of phytobiotics may be depends on the synergistic mechanism among their active molecular complex (Hussein et al., 2020a). Phytobiotics could maintain or improve normal intestinal architecture, increase the villus length and consequently increase the surface of intestinal absorption (Tabatabaei, 2016). It has been demonstrated that phytobiotics are able to stimulate saliva production, secretion of digestible enzymes and bile production resulting in improving the performance and digestibility (Alloui et al., 2014). Moreover, phytobiotics enhance the digestion and digestion and utilization of protein in the intestine (El-Gendi, 1996), decrease the gut pathogens (Kubkomawa et al., 2013) and increase Lactobacillus spp. count (Windisch et al., 2008). It has been observed that supplementation with herbal feed additives can alter the histological structure of the intestine and indicated elevation of the intestinal villi by deepening of its crypts (Murali et al., 2012), increasing the dendritic cells absorption capacity in the intestinal lumen, stimulation of toll-like receptors and activation of epithelial to release the mucosal cytokines. Alcicek et al. (2004) assumed that feeding of broilers on phytobiotics stimulated the secretion of high amount of intestinal mucus and consequently reducing the pathogens adhesion and establishment of gut microbial eubiosis.

Supplementing broiler feed or water with essential oil mixtures of thymol and cinnamaldehyde (Tiihonen et al., 2010), thymol and star anise (Kim et al., 2016), clove and cinnamaldehyde (Chalghoumi et al., 2013), coriander (Ghazanfari et al., 2015; Hady et al., 2016), oregano (Hashemipour et al., 2014), a mixture of oregano, anise, and citrus peel (Abdelnaser et al., 2019), carvacrol (Jamroz et al., 2006), a blend of carvacrol, cinnamaldehyde and capsicum oleoresin (Bravo and Ionescu, 2008) and ginger extract (Olaifa et al., 2019) had been detected for improving all performance parameters including; feed intake, feed conversion rate and body weight. Moreover, supplementation of broilers diet with garlic (Elagib et al., 2013), a mixture of garlic, mushroom and propolis (Daneshmand et al., 2012), turmeric powder (Ahmadi, 2010), guggul resin (Iranparast et al., 2014), dried ground leaves of stevia (Atteh et al., 2008) and black cumin seeds (Khalaji et al., 2011) presented the enhancement of broilers performance. Studies on the effects of herbal compounds on the production of broilers
Japanese quail's revealed improvement of all performances (Manafi et al., 2016).

The laying hens represented improvement in egg production, eggshell strength and thickness as well as internal egg quality after treatment with mixture of plant extracts and essential oils (Bölükbaşi et al., 2008; Radwan et al., 2008; Kaya et al., 2013).

\section{Antimicrobial effect}

It has been demonstrated that phytochemical compounds of phytobiotics have a strong antimicrobial activity against Gram-positive and Gram-negative bacteria either in vivo (Al-Kassie, 2010; Daka, 2013) or in vitro environment (Al-Mariri and Safi, 2014). Some phytochemical compounds as alkaloid inhibit DNA synthesis (Karou et al., 2005) and form saponin complexes with the cell membrane (sterols) which leading to cells damage and collapse (Morrissey and Osbourn, 1999). The antimicrobial effect of essential oils could be refer their ability to penetrate through the bacterial membrane (Helander et al., 1998), their chemical structure (Farag et al., 1989) and their aromaticity (Bowles and Miller, 1993).

Modulation of the gut microflora by phytogenic compounds plays an important role in maintaining host health (Tollba et al., 2012). Several studies revealed that phytogenic compounds or their extracts reduce the population of intestinal pathogenic organisms and their metabolites, but increase the number of intestinal normal and helpful microflora which relief the intestinal challenge and immune stress and consequently increase intestinal performance (Liu et al., 2014). It has been speculated that organic acids of some phytobiotic feed additives may lower the intestinal $\mathrm{pH}$ that leaded to inhibiting the pathogenicity of local pathogens and lowering the level of their toxic products (Manafi et al., 2016).

\section{Antibacterial effect}

Essential oils could reduce the growth of common intestinal poultry pathogens. Inoculation of thyme and cinnamon in the broiler ration reduces the total bacterial as well as coliform count in the intestinal tract (Karangiya et al., 2016). An in vitro study revealed that flowers of Calendula presented growth inhibitory effects on Escherichia coli (E. coli) (Arora et al., 2013). However, some reports indicated the inhibitory effects of dietary phytobiotics or plant extracts on E. coli activity in vivo (Abd El-Ghany and Ismail, 2014; Diaz-Sanchez et al., 2015; Elmenawey et al., 2019). Diet containing thyme essential oil helped for increasing in Lactobacillus and decreasing in $E$. coli counts in the intestine of Japanese 
quail (Khaksar et al., 2012). Essential oils of oregano revealed antimicrobial properties on broiler carcasses through reduction of the total bacterial count especially Salmonella spp. (Aksit et al., 2006). Short chain fatty acids of phytobiotics revealed growth promoting effect on the intestinal beneficial microbiota as well as controlling the growth of Salmonella enteritidis (S. enteritids) (Hansen et al., 1997). Quail's diet containing phytobiotic feed additives had significant $(\mathrm{P} \leq 0.05)$ increase in the number of Lactobacilli, decrease in E. coli population and inhibit the growth of Salmonella in the intestinal tract (Dorman and Deans, 2000).

The efficacy of a mixture of seven essential oils that inhibited the growth of Clostridium perfringens ( $C$. perfringens) in vitro has been reported by Si et al. (2009). In the field studies of Mitsch et al. (2004), Siragusa et al. (2008), McReynolds et al. (2009), Abudabos et al. (2018), El-Sheikh et al. (2018) and Hussein et al. (2020b), different phytobiotic feed additives caused reduction of intestinal colonization and proliferation of $C$. perfringens, lesion score and mortalities as well as improvement in performance of broilers and their carcass quality.

The reduction in $C$. perfringens virulence after supplementation with essential oil compounds may be related to the stimulation of some digestible enzymes like trypsin which inactivates $\alpha$ toxin of type A and $\beta$ toxin of type $C$ strains of $C$. perfringens, stabilization of natural resident gut microflora like Lactobacillus spp. and consequently inhibition of the organism pathogenicity (Cho et al., 2014).

Moreover, essential oils of lemon, green tea and turmeric blend proved great efficacy in reducing the count of S. enteritidis and Campylobacter jejuni on the surface of chicken's carcass (Murali et al., 2012). The Eucalyptus volatile oils have been found to have the ability to relief broilers complicated respiratory distress caused by Mycoplasma gallisepticum (Abd El-Ghany, 2008).

\section{Antifungal and detoxifying effect}

Phytogenic compound have antifungal properties. Akgul and Kivanc (1988) reported about the inhibitory effects of some spices and oregano components on some foodborne fungi. Essential oil of marjoram reduced the in vitro growth of Aspergillus flavus, A. niger, A. ochraceus and A. parasiticus up to $89 \%$ (Deans and Waterman, 1993). The oil of lemon and orange can reduce the formation of A. flavus (Hasan et al., 2005). It has been demonstrated that Allium sativum has a great (60-80\%) in vitro antifungal activity against Aspergillus and Penicillium spp. (Afzal et al., 2010). Onion, garlic and ginger revealed antifungal activity against A. flavus, A. niger and Cladosporium herbaru, Cinnamomum verum and Piper nigrum which was studied with successful results by Tagoe et al. (2011). Phytobiotics like Ocimum gratissimum, Cymbopogon citratus, Xylopia aethiopica, Monodora myristica, Syzygium aromaticum proved their ability to inhibit the formation of non sorbic acid which is a precursor in the pathway of aflatoxin synthesis (Awuah, 1996). Neem extract represented inhibitory effects on biosynthesis of aflatoxins (B and G) (Bhatnagar et al., 1990). Also, neem leaf extract and its oil have been found to inhibit the growth and morphology of Penicillium spp. and consequently prevent the production of ochratoxin $\mathrm{A}$ (Bhatnagar et al., 1990).

\section{Anticoccidial effect}

The anticoccidial activity of some herbal plants have been documented (Willis et al., 2013). Phytogenic compounds have been found to reduce the severity of Eimeria spp. infection in broilers by alleviation of droppings score, intestinal lesions score and also reducing oocyst shedding (Zyan et al., 2017). Numerous phytobiotics as Atemesia annua (Allen et al., 1997), Astragulus membranaceus and Sophora flavescens (Youn and Noh, 2001), green tea (Jang et al., 2007), Ageratum conyzoid (Nweze and Obiwulu, 2009), Musa paradisiaca (Anosa and Okoro, 2010), olive tree (De Pablos et al., 2010), oregano essential oil (Tsinas et al., 2011), Carica papaya leaf extract (Nghonjuyi et al., 2015) and coconut oil (Hafeez et al., 2020) have indicated an excellent anticoccidial activity against different types of Eimeria spp. in birds.

Some essential oils presented similar drug efficacy in prevention and control of coccidiosis in broilers. The oregano oil and other mixtures of oils were similar to ionophores lasalocid (Giannenas et al., 2003) and monensin (Oviedo-Rondón et al., 2006), while a mixture of carvacrol, camphor, cineole and thymol was similar to salinomycin (Bozkurt et al., 2014) in terms of reduction of shedding and lesions of different Eimeria spp. in broilers.

Combined experimental infection of $C$. perfringens and E. maxima has been ameliorated after dietary treatment of three breeds of broilers with Capsicum, Curcuma longa oleoresins (Kim et al., 2015) and Allium hookeri root (Lee et al., 2018).

\section{Immunomodulatory effect}

In poultry production, reduction of infection as well as improvement of production by stimulation of the immune system after using phytogenic substances were 
investigated previously (Zaki et al., 2016). The immunomodulatory mechanism of phytogenic active substances in poultry have been studied (Hashemi and Davoodi, 2012). Polysaccharide are very important immunoactive components of phytobiotics (Xue and Meng, 1996). Phytogenic compounds also induce their immunomodulatory effects through increasing immune cells proliferation, arising cytokines expression and elevation of antibody titers (Lee et al., 2010; Park et al., 2011; Pourhossein et al., 2015). The immunogenicity of phytobiotics could be manifested as increasing macrophages, lymphocytes and natural killer cells activities as well as stimulation of interferon production (Hashemi and Davoodi, 2010; Kumar et al., 2014). Plants contain flavonoids, vitamin $\mathrm{C}$ and carotenoids are able to enhance the immune system (Craig, 1999). Some herbs and species like garlic, echinacea and liquoric have immunostimulatory properties due to their composition of vitamin $\mathrm{C}$, carotenoids and flavonoids as well as their abilities to stimulate macrophages, lymphocytes and natural killer cells activities and interferon production (Frankic et al., 2009). Detecting in vitro immunostimulatory effect of dandelion, mustard and safflower either on lymphocytes and macrophages of chickens was performed by Lee et al. 2007. The results indicated inhibition of tumor cell growth, antioxidant effects, stimulation of lymphocyte proliferation and nitric oxide production by macrophages. The immunostimulant effect of some essential oils extracts of phytobiotics may be due to the presence of certain compounds that may bind to Immunoglobulin $\mathrm{G}$ ( $\mathrm{Ig} G$ ) receptors which leaded to stimulation of immune response (Ahmed et al., 2013). In the study of Placha et al. (2014), inoculation of thymol in the broiler diet increased the trans-epithelial electrical resistance of duodenal mucosa.

It has been found that mushroom and plant polysaccharides have immunomodulatory effects in chickens infested with Eimeria tenella (Guo et al., 2004).

Potential antiviral activity of plant seeds was recorded (Yaseen, 2003). Different types of herbs mix, spices, plant extracts and essential oils presented enhancement of immune response of birds (Huang et al., 2007; Pourali et al., 2010; Kavyani et al., 2012; AbouElkhair et al., 2014; Awaad et al., 2016).

A significant $(\mathrm{P}<0.05)$ elevation of antibody Enzyme-linked immunosorbent assay (ELISA) titer after vaccination with Newcastle Disease Virus (NDV) vaccine (Chowdhury et al., 2018) was recorded after feeding on clove bud and cinnamon plant, while peppermint essential oil helped in significant $(\mathrm{P}<0.05)$ rising in
Haemagglutination Inhibition (HI) antibody titer against Avian Influenza (AI) virus vaccines (H9N2) in broiler chicks (Sultan et al., 2017). In addition, significant $(\mathrm{P}<0.05)$ increase in $\mathrm{HI}$ titers against NDV vaccine and sheep red blood cells were observed in broiler chicks treated with Aloe vera gel $(1 \%)$ in the drinking water for six weeks (Darabighane et al., 2017)

Laying hens presented significant $(\mathrm{P}>0.05)$ increase in ELISA titer after vaccination with $\mathrm{ND}$, Infectious Bronchitis (IB) and Infectious Bursal Disease (IBD) vaccines (Özek et al., 2011). Landy et al. (2011) observed that inoculation of broiler ration with neem powder for six weeks resulting in an elevation of $\mathrm{HI}$ antibody titer against AI vaccine, but not against ND vaccine. Barbour et al. (2008) evaluated the effect of using Eucalyptus and peppermint essential oils during vaccination of ND and IBD. The results indicated improved health conditions of the birds associated with elevation of ELISA titers against the used virus vaccines. Moreover, an increase in IgG and IgM ELISA titers has been observed in chickens fed on oregano essential oils for three weeks period (Malayoglu et al., 2010). Recently, Abdelnaser et al. (2019) indicated that treatment with essential oils of oregano, anise, and citrus peel at level of $125 \mathrm{gm} / \mathrm{ton}$ induced positive effects on the immune response of $C$. perfringens challenged broilers after vaccination against ND, IB, AI and IBD viruses as well as increasing in relative spleen weight.

\section{CONCLUSION}

Using of phytobiotics in poultry diet as a feed additive and considering them as an antimicrobial substitute has been became a very essential and critical issue currently. Phytobiotic compounds could replace antibiotic growth promoters to improve the productive performance of chickens, act as antibacterial, antifungal and antiparasitic agents as well as it has been considered as potential immunostimulants especially after routine vaccination programs of chickens. This review spotlight on the significant using of phytobiotics in poultry field and industry as natural antibiotic alternatives to avoid the emerged problem of antibiotic resistance,

\section{Competing interests}

The author have not declared any conflict of interest.

\section{REFERENCES}

Abd El-Ghany WA (2008). Assessment of the efficacy of certain antibiotics and volatile oils for the treatment of induced ycoplasma gallisepticum infection in broiler chickens. Journal of the Egyptian 
Veterinary Medical Association, 69: 283-307. Avaialble at: https://scholar.cu.edu.eg/?q=wafaaabdelghany/publications/assessm ent-efficacy-certain-antibiotics-and-volatile-oils-treatment-ind

Abd El-Ghany WA and Ismail M (2014). Tackling experimental colisepticaemia in broiler chickens using phytobiotic essential oils and antibiotic alone or in combination. A mixture of essential oils of Oreganum aetheroleum is more effective compared with ciprofloxacin in the treatment of $E$. coli in broiler chickens. Iranian Journal of Veterinary Research, 15: 110-115. DOI: https://www.dx.doi.org/10.22099/ijvr.2014.2341

Abdelnaser AHT, Moustafa MMA and Abd El-Haleem MI (2019). Effect of using synbiotics and essential oils on performance parameters and immune response of necrotic enteritis challenged broiler chicks. Benha Veterinary Medical Journal, 36: 373-380. DOI: https://www.dx.doi.org/10.21608/BVMJ.2019.15094.1051

Abudabos AM, Alyemni AH, Dafalla YM and Khan RU (2018). The effect of phytogenics on growth traits, blood biochemical and intestinal histology in broiler chickens exposed to Clostridium perfringens challenge. Journal of Applied Animal Research, 46: 691-695.

https://www.doi.org/10.1080/09712119.2017.1383258

Abou-Elkhair R, Ahmed HA and Selim S (2014). Effects of black pepper (Piper nigrum), turmeric powder (Curcuma longa) and coriander seeds (Coriandrum sativum) and their combinations as feed additives on growth performance, carcass traits, some blood parameters and humoral immune response of broiler chickens. Asian Australasian Journal of Animal Sciences, 27: 847-854. DOI:https://www.dx.doi.org/10.5713\%2Fajas.2013.13644

Afzal R, Mughal S M, Munir M, Sultana K, Qureshi R, Arshad M and Laghari MK (2010). Mycoflora associated with seeds of different sunflower cultivars and its management. Pakistan Journal of Botany, 42: 435-345. Available at: http://www.pakbs.org/pjbot/PDFs/42(1)/PJB42(1)435.pdf

Ahmed ST, Hossain ME, Kim GM, Hwang JA, Ji H and Yang CJ (2013). Effects of resveratrol and essential oils on growth performance immunity, digestibility and fecal microbial shedding in challenged piglets. Asian Australasian Journal of Animal Sciences, 26: 683690. DOI: https://www.dx.doi.org/10.5713\%2Fajas.2012.12683

Ahmadi F (2010). Effect of turmeric (Curcumin longa) powder on performance, oxidative stress state and some of blood parameters in broilers fed on diets containing aflatoxin. Global Veterineria, 5: 312-317. Available at: http://www.idosi.org/gv/gv5(6)10/4.pdf

Akgul A, and Kivanc M (1988). Inhibitory effects of selected Turkish spices and oregano components on some foodborne fungi. . International Journal of Food Microbiology, 6: 263-268. DOI: https://www.doi.org/10.1016/0168-1605(88)90019-0

Aksit M, Goksoy E, Kok F, Ozdemir D and Ozdogan M (2006). The impacts of organic acid and essential oil supplementations to diets on the microbiological quality of chicken carcasses. Archiv fur Geflugelkund, 70: 168-173. Available at: https://www.europeanpoultry-science.com/The-impacts-of-organic-acid-and-essential-oilsupplementations-to-133diets-on-the-microbiological-quality-ofchickencarcasses,QUIEPTQyMTcxOTQmTUIEPTE2MTAxNA.ht $\mathrm{ml}$

Alagawany M, AbdEl-Hack ME, Al-Sagheer AA, Naiel MA, Saadeldin IM and Swelum AA (2018). Dietary cold pressed water cress and coconut oil mixture enhances growth performance, intestinal microbiota, antioxidant status, and immunity of growing rabbits. $\begin{array}{llll}\text { Animals, } & 8: & 212 . & \text { DOI: }\end{array}$ https://www.dx.doi.org/10.3390\%2Fani8110212

Alcicek A, Bozkurt M and Çabuk M (2004). The effect of a mixture of herbal essential oils, an organic acid or a probiotic on broiler performance. South African Journal of Animal Science 34: 217222. Available at: https://hdl.handle.net/10520/EJC94382

Al-Kassie GAM (2010). The effect of thyme and cinnamon on the microbial balance in gastro intestinal tract on broiler chicks.
International Journal of Poultry Science, 9: 495-498. DOI: http://www.dx.doi.org/10.3923/ijps.2010.495.498

Allen PC, Lydon J and Danforth H (1997). Effects of components of Artemisia аппиа on coccidia infections in chickens. Poultry $\begin{array}{llll}\text { Science, } & 76: & 1156-1163 . & \text { DOI: }\end{array}$ https://www.doi.org/10.1093/ps/76.8.1156

Alloui N, Alloui MN, Agabou A (2014). Application of herbs and phytogenic feed additives in poultry production - a review. Global Journal Animal Science Research, 2: 234-243. Available at:http://archives.gjasr.com/index.php/GJASR/article/view/57

Al-Mariri A and Safi M (2014). In vitro antibacterial activity of several plant extracts and oils against some gram-negative bacteria. Iranian Journal of Medical Sciences, 39: 36. Available at:https://www.ncbi.nlm.nih.gov/pubmed/24453392

Al-Sagheer AA, AbdEl-Hack ME, Alagawany M, Naiel MA, Mahgoub SA, Badr MM, Hussein EO, Alowaimer AN and Swelum AA (2019). Paulownia leaves as a new feed resource: Chemical composition and effects on growth, carcasses, digestibility, blood biochemistry, and intestinal bacterial populations of growing rabbits. $\quad$ Animals, 9: 95. https://www.dx.doi.org/10.3390\%2Fani9030095

Anosa GN and Okoro OJ (2010). Anticoccidial activity of the methanolic extract of Musa Paradisiaca root in chickens. Tropical Animal Health and Production, 43: 245-248. DOI: http://www.doi.org/10.1007/s11250-010-9684-1

Arora D, Rani A and Sharma A (2013). A review on phytochemistry and ethnopharmacological aspects of genus Calendula. Pharmacognosy Reviews, 7: 179-187. Available at: https://www.ncbi.nlm.nih.gov/pubmed/24347926

Atteh JO, Onagbesan OM, Tona K, Decuypere E, Geuns JM and Buyse J (2008). Evaluation of supplementary stevia (Stevia rebaudiana, bertoni) leaves and stevioside in broiler diets: effects on feed intake, nutrient metabolism, blood parameters and growth performance. Journal of Animal Physiology and Animal Nutrition, 92: 640-649. DOI: $\quad$ https://www.doi.org/10.1111/j.14390396.2007.00760.x

Awaad MHH, Afify MAA, Zoulfekar SA, Mohammed FF, Elmenawy MA and Hafez HM (2016). Modulating effect of peppermint and eucalyptus essential oils on vVND infected chickens. Pakistan Veterinary Journal, 36: 350-355. Available at: http://www.pvj.com.pk/pdf-files/36 3/350-355.pdf

Awuah RT (1996). Possible utilization of plant products in grain storage. Proceedings of the Workshop on Mycotoxins in Food in Africa, Nov. 6-10, International Institute of Tropical Agriculture, Benin, p. 32. Available at: http://www.academicjournals.org/AJB

Barbour EK, Yaghi RH, Shaib HA, Tayeb IT and Sleiman FT (2008). Evaluation of an essential oil in treatment of immunosuppressed coinfected broilers. Eurasian Journal of Sustainable Agriculture, 2: 212-218. Available at: http://www.aensi.org/aejsa/2008/212218.pdf

Bhatnagar D, Zeringue HJ and McCormick SP (1990). Neem leaf extracts inhibit aflatoxin biosynthesis in Aspergillus flavus and Aspergillus parasiticus. Proceedings of the USDA Neem Workshop, April 16-17, Beltsville, Maryland, pp. 118-127. Avaialble at: https://agris.fao.org/agrissearch/search.do?recordID=US9164967

Bölükbaşi ŞC, Erhan MK and Kaynar Ö (2008). The effect of feeding thyme, sage and rosemary oil on laying hen performance, cholesterol and some proteins ratio of egg yolk and Escherichia coli count in feces. Archiv fur Geflugelkund, 72: 231-237. Available at: https://www.european-poultry-science.com/The-effect-of-feedingthyme-sage-and-rosemary-oil-on-laying-hen-performancecholesterol-and-some-proteins-ratio-of-egg-yolk-and-span-classwsname-Escherichia-Colispan-cou,QUIE

Bote CJL (2004). Bioflavonoid's effects reach beyond productivity. Feed Mix, 12: 12-15. 
Bowles BL and Miller AJ (1993). Antibotulinal properties of selected aromatic and aliphatic aldehydes. Journal of Food production, 56: 788-794. DOI: https://www.doi.org/10.4315/0362-028x-56.9.788

Bozkurt M, Aysul N, Küçükyilmaz K, Aypak S, Ege G, Çatli A U, Akúit H, Çöven F, Seyrek K and Çınar M (2014). Efficacy of in-feed preparations of an anticoccidial, multienzyme, prebiotic, probiotic, and herbal essential oil mixture in healthy and Eimeria spp.infected broilers. Poultry Science, 93: 389-399. DOI: https://www.doi.org/10.3382/ps.2013-03368

Bravo D, and Ionescu C (2008). Meta-analysis of the effect of a mixture of carvacrol, cinnamaldehyde and capsicum oleoresin in broilers. Poultry Science, 87: 75. Available at: https://www.researchgate.net/publication/298327084 Metaanalysis of the effect of a mixture of carvacrol cinnamaldehyde and c apsicum oleoresin in broilers

Castanon JIR (2007). History of the use of antibiotic as growth promoters. Journal of Poultry Science, 86: 2466-2471. DOI: https://www.doi.org/10.3382/ps.2007-00249

Chalghoumi R, Belgacem A, Trabelsi I, Bouatour Y and Bergaoui R (2013). Effect of dietary supplementation with probiotic or essential oils on growth performance of broiler chickens. International Journal of Poultry Science, 12: 538-344. DOI: http://www.dx.doi.org/10.3923/ijps.2013.538.544

Cho JH, Kim HJ and Kim IH (2014). Effects of phytogenic feed additive on growth performance, digestibility, blood metabolites, intestinal microbiota, meat color and relative organ weight after oral challenge with Clostridium perfringens in broilers. Livestock Science, $\quad 160$ : $\quad 82-88 . \quad$ DOI: https://www.doi.org/10.1016/j.livsci.2013.11.006

Chowdhury S, Mandala G, Patraa A, Kumara P, Samantab I, Pradhanc S, Chowdhurya A, Mandala G, Patraa A, Kumara P et al. (2018). Different essential oils in diets of broiler chickens: 2. Gut microbes and morphology, immune response, and some blood profile and antioxidant enzymes. Animal Feed Science and Technology, 236: 39-47. DOI: https://www.doi.org/10.1016/j.anifeedsci.2017.12.003

Craig WJ (1999). Health-promoting properties of common herbs. American Journal of Clinical Nutrition, 70: 491-499. DOI: https://www.doi.org/10.1093/ajen/70.3.491s

Daka D (2013). Antibacterial effect of garlic (Allium sativum) on Staphyloccus aureus: An in vitro study. African Journal of Biotechnology, 10: 666-669. Available at: http://www.academicjournals.org/AJB

Daneshmand A, Sadeghi GH and Karimi A (2012). The effects of a combination of garlic, oyster mushroom and propolis extract in comparison to antibiotic on growth performance, some blood parameters and nutrients digestibility of male broilers. Brazilian Journal of Poultry Science, 14: 141-147. DOI: https://www.doi.org/10.1590/S1516-635X2012000200009

Darabighane B, Mahdavi A, Aghjehgheshlagh F, Zarei A, Kasapidou El and Nahashon S (2017). Effect of Aloe vera and vitamin E supplementation on the immune response of broilers. Revista Colombiana de Ciencias Pecuarias, 30: 159-164. DOI: http://www.dx.doi.org/10.17533/udea.rccp.v30n2a07

Deans SG and Waterman PG (1993). Biological Activities of Volatile Oils. In: Volatile Oil Crops: Their Biology, Biochemistry and Production, Hay, R.K.M. and P.G. Waterman (Eds.). Longman, London, UK, pp. 97-111. Available at: https://agris.fao.org/agrissearch/search.do?recordID=GB9405744

De Pablos LM, dos Santos MF, Montero E, Garcia-Granados A, Parra A and Osuna A (2010). Anticoccidial activity of maslinic acid against infection with Eimeria tenella in chickens. Parasitology Research, 107: 601-604. DOI: https://www.doi.org/10.1007/s00436-0101901-3

Diaz-Sanchez S, D’Souza D, Biswas D and Hanning I (2015). Botanical alternatives to antibiotics for use in organic poultry production. Poultry Science, 94: 1419-1430. DOI: https://www.doi.org/10.3382/ps/pev014
Dorman HJ and Deans SG (2000). Antimicrobial agents from plants: Antibacterial activity of plant volatile oils. Journal of Applied Microbiology, $\quad 88: \quad 308-316 . \quad$ DOI: https://www.doi.org/10.1046/j.1365-2672.2000.00969.x

Elagib HAA, El-Amin WIA, Elamin KM and Malik HEE (2013). Effect of dietary garlic (Allium sativum) supplementation as feed additive on broiler performance and blood profile. Journal of Animal Science Advances, 3: 58-64. Available at: Link

El-Gendi GM (1996). Effect of feeding dietary herbal feed additives on productive and metabolic responses of broiler chicks. Egyptian Poultry Science, 16: 395-412. Available at: https://www.scirp.org/(S(czeh2tfqyw2orz553k1w0r45))/reference/ ReferencesPapers.aspx?ReferenceID $=1656208$

Elmenawey MA, Mohammed FA, Morsy EA, Abdel-Alim GA and Awaad MHH (2019). The impact of essential oils blend on experimental colisepticemia in broiler chickens. International Journal of Veterinary Science, 8: 294-299. Available at: http://www.ijvets.com/pdf-files/Volume-8-no-4-2019/294-299.pdf

El-Sheikh SM, Khairy MH, Eleiwa NZ, Abdalla OE and El-Monsef AGA (2018). Effect of sanguinarine phytobiotic, sodium butyrate compared to ampicillin on controlling necrotic enteritis in broiler chickens. In Proceedings of the Veterinary Medicine In-between Health \& Economy (VMHE), Cairo, Egypt, 16-19 October 2018,Volume 55. DOI: https://doi.org/10.26873/SVR-668-2018

Europe Union Commission (2005). Ban on antibiotics as growth promoters in animal feed enters into effect. Regulation 1831/2003/EC on additives for use in animal nutrition, replacing Directive 70/524/EEC on additives in feed- stuffs, Brussels, 22 December. Available at: https://ec.europa.eu/commission/presscorner/detail/en/IP_05_1687

Farag RS, Badei AZMA, Hewedi FM and El-Baroty GSA (1989). Antioxidant activity of some spice essential oils on linoleic acid oxidation in aqueous media. Journal of the American Oil Chemists' Society, 66 : 792-799. https://www.doi.org/10.1007/BF02653670

Frankic T, Voljg M, Salobir J and Rezar V (2009). Use of herbs and spices and their extracts in animal nutrition. Actaagriculturae Slovenica, 92: 95-102. Available at: http://aas.bf.uni-1j.si/zootehnika/94-2009/PDF/94-2009-2-95102.pdf

Ghazanfari S, Mohammadi Z and Moradi AM (2015). Effects of coriander essential oil on the performance, blood characteristics, intestinal microbiota and histology of broilers. Brazilian Journal of Poultry Science, 17: 419-426. DOI: https://www.doi.org/10.1590/1516-635X1704419-426

Gheisar MM and Kim IH (2018). Phytobiotics in poultry and swine nutrition - a review. Italian Journal of Animal Science, 17: 92-99. DOI: https://www.doi.org/10.1080/1828051X.2017.1350120

Giannenas I, Florou-Paneri P, Papazahariadou M, Christaki E, Botsoglou NA and Spais AB (2003). Effect of dietary supplementation with oregano essential oil on performance of broilers after experimental infection with Eimeria tenella. Archives of Animal Nutrition, 57: 99-106. DOI: https://www.doi.org/10.1080/0003942031000107299

Gilani SMH, Zehra S, Hassan F, Galani S and Ashraf A (2018). Effect of natural growth promoters on immunity, and biochemical and haematological parameters of broiler chickens. Tropical Journal of Pharmaceutical Research, 17: 627-633. DOI: https://www.doi.org/10.4314/tipr.v17i4.9

Guo FC, Kwakkel RP, Williams BA, Parmentier HK, Li WK, Yang ZQ and Verstegen MW (2004). Effects of mushroom and herb polysaccharides on cellular and humoral immune responses of Eimeria tenella-infected chickens. Poultry Science, 83: 1124-1132. DOI: https://www.doi.org/10.1093/ps/83.7.1124

Hady MM, M Zaki MM, Abd El-Ghany WA and Korany RMS (2016). Assessment of the broilers performance, gut healthiness and carcass characteristics in response to dietary inclusion of dried coriander, turmeric and thyme. International Journal of Environmental and 
Agriculture Research, 2: 153-159. Available at: https://issuu.com/ijoear-environmentalandagriculturer

Hafeez A, Ullah Z, Khan RU, Qudrat U and Naz S (2020). Effect of diet supplemented with coconut essential oil on performance and villus histomorphology in broiler exposed to avian coccidiosis. Tropical Animal Health and Production, 52: 2499-2504. DOI: https://www.doi.org/10.1007/s11250-020-02279-6

Hansen LL, Larsen AE, Jensen BB and Hansen-Moller J (1997). Short time effect of zinc bacitracin and heavy fouling with faeces plus urine on boar taint. Journal of Animal Science, 64: 351-563. DOI: https://www.doi.org/10.1017/S1357729800015927

Hasan MM, Chowdhury SP, Alam S, Hossain B and Alam MS (2005). Antifungal effects of plant extracts on seed-borne fungi of wheat seed regarding seed germination, Seedling health and vigour index. Pakistan Journal of Biological Sciences, 8: 1284-1289. DOI: http://www.dx.doi.org/10.3923/pjbs.2005.1284.1289

Hashemi SR and Davoodi H (2010). Phytogenics as new class of feed additive in poultry industry. Journal of Animal and Veterinary Advances, $\quad 9: \quad 2295-2304 . \quad$ DOI: http://www.dx.doi.org/10.3923/javaa.2010.2295.2304

Hashemi SR and Davoodi H (2012). Herbal plants as new immunostimulator in poultry industry: A review. Asian Journal of Animal and Veterinary Advances, 7: 105-116. DOI: http://www.dx.doi.org/10.3923/ajava.2012.105.116

Hashemipour H, Kermanshahi H, Golian A and Khaksar V (2014). Effects of carboxy methyl cellulose and thymol + carvacrol on performance, digesta viscosity and some blood metabolites of broilers. Journal of Animal Physiology and Animal Nutrition, 98: 672-679. DOI: https://www.doi.org/10.1111/jpn.12121

Helander IM, Alakomi HL, Latva-Kala K, Mattila-Sandholm T, Pol I, Smid EJ, Gorris LGM and von Wright A (1998). Characterization of the action of selected essential oil components on gram-negative bacteria. Journal of Agricultural and Food Chemistry, 46: 35903595. DOI: https://www.doi.org/10.1021/jf980154m

Huang RL, Deng ZYC, Yang YL, Yin Xie MY, Wu GY, Li TJ, Li LL, Tang ZR, Kang P, Hou ZHP et al. (2007). Dietary oligochitosan supplementation enhances immune status of broilers. Journal of Science of Food and Agriculture, 87: 153-159. DOI: https://www.doi.org/10.1002/jsfa.2694

Hussein EOS, Ahmed SH, Abudabos AM, Suliman GM, Abd El-Hack ME, Swelum AA and Alowaimer AN (2020a). Ameliorative effects of antibiotic-, probiotic- and phytobiotic-supplemented diets on the performance, intestinal health, carcass traits, and meat quality of Clostridium perfringens-infected broilers. Animals 10: 669. DOI: https://www.doi.org/10.3390/ani10040669

Hussein EOS, Ahmed SH, Abudabos AM, Aljumaah MR, Alkhlulaifi MM, Nassan MA, Suliman GM, Naiel MAE and Swelum AA (2020b). Effect of antibiotic, phytobiotic and probiotic supplementation on growth, blood indices and intestine health in broiler chicks challenged with Clostridium perfringens. Animals, 10: 507. DOI: https://www.doi.org/10.3390/ani10030507

Iranparast F, Parsaei S, Houshmand M and Naghiha A (2014). The effect of oral consumption of guggul (Commiphora mukul) resin on performance and humoral immunity response of broilers. International Journal of Advanced Biological and Biomedical Research, 2: $\quad 802-810 . \quad$ Available at: http://www.ijabbr.com/article 7237 c88f2b6f14b9d63e28ab48d31 $\underline{7528 \mathrm{e} 06 . \mathrm{pdf}}$

Jamroz D, Wertelecki T, Houszka M and Kamel C (2006). Influence of diet type on the inclusion of plant origin active substances on morphological and histochemical characteristics of the stomach and jejunum walls in chicken. Journal of Animal Physiology and Animal Nutrition, 90: 255-268. DOI: https://www.doi.org/10.1111/j.1439-0396.2005.00603.x

Jang SI, Jun MH, Lillehoj HS, Dalloul RA, Kong Il-K, Kim S and Min W (2007). Anticoccidial effect of green tea-based diets against
Eimeria maxima. Veterinary Parasitology, 144: 172-175. DOI: https://www.doi.org/10.1016/s0304-4017(01)00385-5

Karangiya VK, Savsani HH, Patil SS, Garg DD, Murthy KS, Ribadiya NK and Vekariya SJ (2016). Effect of dietary supplementation of garlic, ginger and their combination on feed intake, growth performance and economics in commercial broilers. Veterinary World, 9: 245-250. Availble at: https://www.ncbi.nlm.nih.gov/pubmed/27057106

Karou D, Savadogo A, Canini A, Yameogo S, Montesano C, Simpore J, Colizzi V and Traore A S (2005). Antibacterial activity of alkaloids from Sida acuta. African Journal of Biotechnology, 4: 1452-1457. Available at: http://www.academicjournals.org/AJB

Kavyani A, Zare Shahne A, PorReza J, Jalali Haji-abadi SMA and Landy N (2012). Evaluation of dried powder of mushroom (Agaricus bisporus) as an antibiotic growth promoter substitution on performance, carcass traits and humoral immune responses in broiler chickens. Journal of Medicinal Plants Research, 6: 94-100. DOI: https://www.doi.org/10.5897/JMPR11.1168

Kaya A, Kaya H, Macit M, Celebi S, Esenbuga N, Yoruk MA and Karaoglu M (2013). Effects of dietary inclusion of plant extract mixture and copper into layer diets on egg yield and quality, yolk cholesterol and fatty acid composition. Kafkas Universitesi Veteriner Fakultesi Dergisi, 19: 673-679. Available at:http://vetdergi.kafkas.edu.tr/extdocs/2013_4/673-679.pdf

Khaksar V, Van Krimpen MM, Hashemipour H and Pilevar M (2012). Effects of thyme essential oil on performance, some blood parameters and ileal microflora of Japanese quail. Journal of Poultry Science, 49: 106-110. DOI: https://www.doi.org/10.2141/jpsa.011089

Khalaji S, Zaghari M, Hatami K, Hedari-Dastjerdi S, Lotfi L and Nazarian H (2011). Black cumin seeds, Artemisia leaves (Artemisia sieberi), and Camellia L. plant extract as phytogenic products in broiler diets and their effects on performance, blood constituents, immunity, and cecal microbial population. Poultry Science, 90: 2500-2510. DOI: https://www.doi.org/10.3382/ps.2011-01393

Kim SJ, Lee KW, Kang CW and An BK (2016). Growth performance, relative meat and organ weights, cecal microflora, and blood characteristics in broiler chickens fed diets containing different nutrient density with or without essential oils. Asian Australasian Journal of Animal Science, 29: 549-554. DOI: https://www.dx.doi.org/10.5713\%2Fajas.15.0426

Kim JE, Lillehoj HS, Hong YH, Kim GB, Lee SH, Lillehoj EP and Bravo DM (2015). Dietary Capsicum and Curcuma longa oleoresins increase intestinal microbiome and necrotic enteritis in three commercial broiler breeds. Research in Veterinary Science, 102: 150-158. DOI: https://www.doi.org/10.1016/j.rvsc.2015.07.022

Kubkomawa HI, Nafarnda DW, Mukang SM, Tizhe MA, Tuakam DK, Shua NJ, Ugwu CC, Opara MN, Neils JS and Okoli IC (2013). Ethno-Veterinary health management practices amongst livestock producers in Africa - A review. World Journal of Agricultural Sciences, $\quad 1$ : 252-257. Available at:http://wsrjournals.org/journal/wjas

Kumar M, Kumar V, Roy D, Kushwaha R and Vaiswani S (2014). Application of herbal feed additives in animal nutrition - a review. International Journal of Livestock Research 4: 1-8. DOI: https://www.dx.doi.org/10.5455/ijlr.20141205105218

Landy N, Ghalamkari G, Toghiani M and Yazdi F (2011). Humoral immune responses of broiler chickens fed with antibiotic and neem fruit powder (Azadirachta Indica) as feed additive supplemented diet. International Conference of Life Science and Technology (IPCBEE), 3: 153-155. Available at: http://www.ipcbee.com/vol3/39-L20019.pdf

Lee YS, Lee SH, Gadde UD, Oh ST, Lee SJ and Lillehoj HS (2018). Allium hookeri supplementation improves intestinal immune response against necrotic enteritis in young broiler chickens. Poultry Science, 97: 1899-1908. DOI: https://www.doi.org/10.3382/ps/pey031 
Lee SH, Lillehoj HS, Chun HK, Tuo W, Park HJ, Cho SM, Lee YM and Lillehoj EP (2007). In vitro treatment of chicken peripheral blood lymphocytes, macrophages and tumor cells with extracts of Korean medicinal plants. Nutrition Research, 27: 362-366. DOI: https://www.doi.org/10.1016/j.nutres.2007.04.001

Lee SH, Lillehoj HS, Hong YH, Jang SI, Lillehoj EP, Ionescu C, Mazuranok L and Bravo D (2010). In vitro effects of plant and mushroom extracts on immunological function of chicken lymphocytes and macrophages. British Poultry Science, 51: 213221. DOI: https://www.doi.org/10.1080/00071661003745844

Liu HN, Liu Y, Hu LL, Suo YL, Zhang L, Jin F, Feng XA, Teng N and Li Y (2014). Effects of dietary supplementation of quercetin on performance, egg quality, cecal microflora populations, and antioxidant status in laying hens. Poultry Science, 93: 347-353. DOI: https://www.doi.org/10.3382/ps.2013-03225

Malayoglu HB, Baysal Ş, Misirlioğlu Z, Polat M, Yilmaz H and Turan N (2010). Effects of oregano essential oil with or without feed enzymes on growth performance, digestive enzyme, nutrient digestibility, lipid metabolism and immune response of broilers fed on wheat-soybean meal diets. British Poultry Science, 51: 6780.DOI: https://www.doi.org/10.1080/00071660903573702

Manafi M (2015). Comparison study of a natural non-antibiotic growth promoter and a commercial probiotic on growth performance, immune response and biochemical parameters of broiler chicks. Journal of Poultry Science, 52: 274-281. DOI: https://www.doi.org/10.2141/jpsa.0150027

Manafi M, Hedayati M and Khalaji S (2016). Effectiveness of phytogenic feed additive as alternative to bacitracin methylene disalicylate on hematological parameters, intestinal histomorphology and microbial population and production performance of Japanese quails. Asian Australasian Journal of Animal Sciences, 29: 13001308. DOI: https://www.dx.doi.org/10.5713\%2Fajas.16.0108

McReynolds J, Waneck C, Byrd J, Genovese K, Duke S and Nisbet D (2009). Efficacy of multistrain direct-fed microbial and phytogenetic products in reducing necrotic enteritis in commercial broilers. Poultry Science, 88: 2075-2080. DOI: https://www.doi.org/10.3382/ps.2009-00106

Mitsch P, Zitterl-Eglseer K, Köhler B, Gabler C, Losa R and Zimpernik I (2004). The effect of two different blends of essential oil components on the proliferation of Clostridium perfringens in the intestines of broiler chickens. Poultry Science, 83: 669-675. DOI: https://www.doi.org/10.1093/ps/83.4.669

Morrissey JP and Osbourn AE (1999). Fungal resistance to plant antibiotics as a mechanism of pathogenesis. Microbiology and Molecular Biology Reviews, 63: 708-724. Available at:https://www.ncbi.nlm.nih.gov/pubmed/10477313

Murali N, Kumar-Phillips GS, Rath NC, Marcy J and Slavik MF (2012). Effect of marinating chicken meat with lemon, green tea and turmeric against food borne bacterial pathogens. International Journal of Poultry Science, 11: 326-332. DOI: http://www.dx.doi.org/10.3923/ijps.2012.326.332

Naiel MA, Ismael NE and Shehata SA (2019). Ameliorative effect of diets supplemented with rosemary (Rosmarinus officinalis) on aflatoxin B1 toxicity in terms of the performance, liver histopathology, immunity and antioxidant activity of Nile Tilapia (Oreochromis niloticus). Aquaculture, 511: 734264. DOI: https://www.doi.org/10.1016/j.aquaculture.2019.734264

Nghonjuyi NW, Tiambo CK, Kimbi HK, Manka'a CN, Juliano RS and Lisita F (2015). Efficacy of ethanolic extract of Carica papaya leaves as a substitute of sulphanomide for the control of coccidiosis in Kabir chickens in Cameroon. Journal of Animal Health and Production, $\quad 3$ : 21-27. DOI: http://www.dx.doi.org/10.14737/journal.jahp/2015/3.1.21.27

Nweze NE and Obiwulu IS (2009). Anticoccidial effects of Ageratum Conyzoides. Journal of Ethnopharmacology, 25: 6-9 DOI: https://www.doi.org/10.1016/j.jep.2008.11.014
Olaifa RO, Sogunle OM, Obileye LI, Ibitoye SA, Ayodeji TM, Odutayo OJ and Ogundele MA (2019). Effect of oral administration of three different phytobiotics on growth performance of locally-adapted turkeys. EC Veterinary Science, 4: 656-662. Avialable at: https://www.ecronicon.com/ecve/pdf/ECVE-04-00162.pdf

Oviedo-Rondón EO, Hume ME, Hernández C and Clemente-Hernández $S$ (2006). Intestinal microbial ecology of broilers vaccinated and challenged with mixed Eimeria species, and supplemented with essential oil blends. Poultry Science, 85: 8540860. DOI: https://www.doi.org/10.1093/ps/85.5.854

Özbudak S (2019). Phytobiotics and their roles in broiler nutrition. Journal of Poultry Research, 16: 23-29. DOI: https://www.doi.org/10.34233/jpr.465575

Özek K, Wellmann KT, Ertekin B and Tarm B (2011). Effects of dietary herbal essential oil mixture and organic acid preparation on laying traits, gastrointestinal tract characteristics, blood parameters and immune response of laying hens in a hot summer season. Journal of Animal and Feed Sciences, 20: 575-586. DOI: https://www.doi.org/10.22358/jafs/66216/2011

Park IJ, Cha SY, Kang M, So YS, Go HG, Mun SP, Ryu KS and Jang HK (2011). Effect of proanthocyanidin-rich extract from Pinus radiata bark on immune response of specific-pathogen-free White Leghorn chickens. Poultry Science, 90: 977-982. DOI: https://www.doi.org/10.3382/ps.2010-01160

Placha I, Takacova J, Ryzner M, Cobanova K, Laukova A, Strompfova V, Venglovska K and Faix S (2014). Effect of thyme essential oil and selenium on intestine integrity and antioxidant status of broilers. British Poultry Science, 55: 105-114. DOI: https://www.doi.org/10.1080/00071668.2013.873772

Pourali M, Mirghelenj SA and Kermanshahi H (2010). Effects of garlic powder on productive performance and immune response of broiler chickens challenged with Newcastle disease virus. Global Veterineria, 4: 616-621. Available at: http://www.idosi.org/gv/gv4(6)10/16.pdf

Pourhossein Z, Qotbi AAA, Seidavi A, Laudadio V, Centoducati G and Tufarelli V (2015). Effect of different levels of dietary sweet orange (Citrus sinensis) peel extract on humoral immune system responses in broiler chickens. . Animal Science Journal, 86: 105-110. DOI: https://www.doi.org/10.1111/asj.12250

Radwan N, Hassan RA, Qota EM and Fayek HM (2008). Effect of natural antioxidant on oxidative stability of eggs and productive and reproductive performance of laying hens. International Journal of Poultry Science, 7: 134-150. DOI: http://www.dx.doi.org/10.3923/ijps.2008.134.150

Shad AA, Ahmad S, Ullah R, AbdEl-Salam NM, Fouad H, Ur Rehman N, Hussain H and Saeed W (2014). Phytochemical and biological activities of four wild medicinal plants. Scientific World Journal, 2014: 857363. DOI: www.dx.doi.org/10.1155/2014/857363

Si W, Ni X, Gong J, Yu H, Tsao R, Han Yand Chambers JR (2009). Antimicrobial activity of essential oils and structurally related synthetic food additives towards Clostridium perfringens. Journal of Applied Microbiology, 106: 213-220. DOI: https://www.doi.org/10.1111/j.1365-2672.2008.03994.x

Siragusa GR, Haas GJ, Matthews PD, Smith RJ, Buhr RJ, Dale NM and Wise MG (2008). Antimicrobial activity of lupulone against Clostridium perfringens in the chicken intestinal tract jejunum and caecum. Journal of Antimicrobial Chemotherapy, 61: 853-858. DOI: https://www.doi.org/10.1093/jac/dkn024

Sultan R, Aslam A, Saleem G, Anjum A, Krull W, Kumosani T and Barbour B (2017). Studies on performance, immunity, and safety of broilers vaccinated with killed $\mathrm{H} 9 \mathrm{~N} 2$ vaccine and supplemented with essential oils of Mentofin ${ }^{\circledR}$ in drinking water. International Journal of Applied Research and Veterinary Medicine, 15: 76-84. Available https://www.jarvm.com/articles/Vol15Iss2/Vol15\%20iss2Barbour.p $\underline{\text { df }}$ 
Tabatabaei SN (2016). Effect of olibanum (Boswellia thurifera) as a feed additive on performance, some blood biochemical and intestinal morphology in broiler chicks. Research Opinions in Animal and Veterinary Sciences, 6: 130-134. Available at: http://www.roavs.com/pdf-files/Issue-4-2016/130-134.pdf

Tagoe DNA, Nyarko HD and Akpaka R (2011). A comparison of the antifungal properties of onion (Allium cepa), ginger (Zingiber officinale) and garlic (Alliu msativum) against Aspergillus flavus, Aspergillus niger and Cladosporium herbarum. Research Journal of Medicinal Plant, 5: 281-287. DOI: http://www.dx.doi.org/10.3923/rjmp.2011.281.287

Tiihonen K, Kettunen H, Bento M H L, Saarinen M, Lahtinen S, Ouwehand AC, Schulze H and Rautonen N (2010). The effect of feeding essential oils on broiler performance and gut microbiota. British Poultry Science, 51: 381-392. DOI: https://www.doi.org/10.1080/00071668.2010.496446

Tollba AAH, Shabaan SAM and Abdel-Mageed MAA (2012). Effects of using aromatic herbal extract and blended with organic acids on productive and physiological performance of poultry. Egyptian Poultry Science Journal, 30: 229-248. Available at: http://www.epsaegypt.com/pdf/2010_march/12-\%201179.pdf

Tsinas A, Giannenas I, Voidarou C, Tzora A and Skoufos J (2011). Effects of an oregano based dietary supplement on performance of broiler chickens experimentally infected with Eimeria Acervulina and Eimeria Maxima. Journal of Poultry Science, 48: 194-200. DOI: https://www.doi.org/10.2141/jpsa.010123

Wang L, Piao XL, Kim SW, Piao XS, Shen YB and Lee HS (2008). Effects of Forsythia suspensa extract on growth performance, nutrient digestibility, and antioxidant activities in broiler chickens under high ambient temperature. Poultry Science, 87: 1287-1294. DOI: https://www.doi.org/10.3382/ps.2008-00023

Willis WL, Wall DC, Isikhuemhen OS, Jackson JN, Ibrahim SA, Hur SL and Anike F (2013). Effect of level and type of mushroom on performance, blood parameters and natural coccidiosis infection in floor-reared broilers. . Open Mycology Journal, 7: 1-6. DOI: http://www.dx.doi.org/10.2174/1874437001307010001

Windisch W, Schedle K, Plitzner C and Kroismayr A (2008). Use of phytogenic products as feed additives for swine and poultry. Journal of Animal Science, 86: 140-148. DOI: https://www.doi.org/10.2527/jas.2007-0459

Xue M, and Meng XS (1996). Review on research progress and prosperous of immune activities of bioactive polysaccharides. Journal of Traditional Veterinary Medicine, 3: 15-18. Aviable at: http://www.jstage.jst.go.jp/browse/jpsa

Yaseen SA (2003). Potential antiviral activity of Nigella sativa extracts.

Iraqi Journal of Veterinary Science, 17: 37-40. Available at: https://eurekamag.com/research/004/276/004276713.php
Yasodha T, Jeevitha S, Yogesh S and Ramanan M (2019). Growth performance parameters of broiler chickens as influenced by herbal poultry feed. International Research Journal of Animal and Veterinary Sciences, 1: 26-30. Available at: https://scirange.com/abstract/irjavs.2019.26.30

Youn HJ and Noh JW (2001). Screening of the anticoccidial effects of herb extracts against Eimeria tenella. Veterinary Parasitology, 96: 257-263. DOI: https://www.doi.org/10.1016/s0304-4017(01)003855

Zaki MM, Abd El-Ghany WA, Hady MM and Korany RMS (2016). Effect of certain phytobiotics on the immune response of Newcastle disease vaccinated broiler chickens Asian Journal of Poultry Science, $\quad 10: \quad 134-140 . \quad$ DOI: http://www.dx.doi.org/10.3923/ajpsaj.2016.134.140

Zyan KA, Elshourbagy MA, Aggour G and Abdelfattah MA (2017). Molecular identification of E. tenella in broiler chicks in Kalyoubia governorate and evaluation of different strategies for control cecal coccidiosis. Benha Veterinary Medical Journal, 33: 175-182. DOI: https://www.doi.org/10.21608/BVMJ.2017.43882

Windisch W, Schedle K, Plitzner C and Kroismayr A (2008). Use of phytogenic products as feed additives for swine and poultry. Journal of Animal Science, 86: 140-148. DOI: https://www.doi.org/10.2527/jas.2007-0459

Xue M, and Meng XS (1996). Review on research progress and prosperous of immune activities of bioactive polysaccharides. Journal of Traditional Veterinary Medicine, 3: 15-18.

Yaseen SA (2003). Potential antiviral activity of Nigella sativa extracts. Iraqi Journal of Veterinary Science, 17: 37-40.

Yasodha T, Jeevitha S, Yogesh S and Ramanan M (2019). Growth performance parameters of broiler chickens as influenced by herbal poultry feed. International Research Journal of Animal and Veterinary Sciences, 1: 26-30. Available at: https://scirange.com/abstract/irjavs.2019.26.30

Youn HJ and Noh JW (2001). Screening of the anticoccidial effects of herb extracts against Eimeria tenella. Veterinary Parasitology, 96: 257-263. DOI: https://www.doi.org/10.1016/s0304-4017(01)00385-

Zaki MM, Abd El-Ghany WA, Hady MM and Korany RMS (2016). Effect of certain phytobiotics on the immune response of Newcastle disease vaccinated broiler chickens Asian Journal of Poultry $\begin{array}{llll}\text { Science, } & 10: & 134-140 . & \text { DOI: }\end{array}$ http://www.dx.doi.org/10.3923/ajpsaj.2016.134.140

Zyan KA, Elshourbagy MA, Aggour G and Abdelfattah MA (2017). Molecular identification of E. tenella in broiler chicks in Kalyoubia governorate and evaluation of different strategies for control cecal coccidiosis. Benha Veterinary Medical Journal, 33: 175-182. DOI: https://www.doi.org/10.21608/BVMJ.2017.43882 